\title{
University-Wide Online Learning During COVID-19: From Policy to Practice
}

\author{
https://doi.org/10.3991/ijim.v15i02.18143 \\ Nuengwong Tuaycharoen \\ Dhurakij Pundit University, Bangkok, Thailand \\ nuengwong. tunedpu.ac.th
}

\begin{abstract}
During Thailand's COVID-19 lockdown, all universities in the country must continue their classes in the Summer Semester with online learning. This article described our university's policy and practice to support university-wide online learning while all faculties were working from home. Our enforcement approach included a Learning Management System, a teaching guideline for our instructors, an online training course for the instructors, a quality control process, and a teaching assessment to obtain feedback from students. Our teaching guideline was composed of various requirements from many online learning studies, which were implemented on the university-wide scale. We measured our approach and teaching guideline with student satisfaction for the online course for the entire university. Due to the rushing nature of the situation, many instructors could not finish all teaching preparation before the semester started. However, the results showed that the students were satisfied with their online classes with an average score of 4.54 on a 5-point Likert Scale.
\end{abstract}

Keywords-COVID-19, online learning, distance learning, higher education, education technology

\section{Introduction}

Coronavirus disease 2019 or COVID-19 in short is a new ongoing pandemic causing by a virus [1]. Common symptoms include fever, cough, fatigue, shortness of breath, and loss of smell and taste. The virus can be spread with close contact via small droplets, including coughing, sneezing, and talking. It was first identified in December 2019 in Wuhan, China. By the end of August, there are more than 23 million cases with more than 800,000 deaths around the world.

During the COVID-19 pandemic, many national governments lock down all facilities in their countries including schools to prevent the disease from spreading. Thailand's lockdown started in late March 2020, and the school shutdown lasted until the end of June. Therefore, many educational institutions enforced their employees to work from home since late March, they and announced that all courses in their summer semester to be delivered online. Many educational institutions, including schools and universities, tried to set up systems to support online learning rapidly. 
All educational institutions must continue their teaching and learning activities through $100 \%$ online learning while no institutions had operated online entirely before. Most universities had online learning as a complementary or non-credit course delivery. Therefore, there were many challenges to prepare and deliver classes online in a very short period of time, including the decision to choose effective communication channels between the instructors and the learners, students' lacking equipment to connect to their classes, students' lacking high-speed internet connection, students' lacking lab instrument, appropriate pedagogy styles for online learning, proper environment for student's online learning, course assessment method through an online channel, plagiarism, IT support methods for both instructors and students, etc. These challenges must be addressed, educated, and solved or minimized the negative consequences while the instructors delivered their courses.

Due to the sudden nature of the situation, no time for our university to conduct any research or any formal face-to-face instructor training for this specific situation. Even though copious research had been done for online learning, but no literature mentioned how to implement online learning at the university-wide scale. The objective of this article is to propose a policy enforcement method and a guideline for online learning in our university and measure its effectiveness through student satisfaction. So, we were trying to find the answer to our research question: What is the appropriate method to make all instructors in our university deliver their Summer course $100 \%$ online with student satisfaction?

Before the outbreak, our university's e-learning platform was used complementary to face-to-face regular education, mainly for accessing materials. Our university also rapidly announced the online learning policy, set up a system to support online learning, and created a guideline for our instructors. This article describes the policy enforcement approach in our university, including the training for online learning, the guideline provided, and the quality assurance process, and support for our faculties during this crisis. Additionally, we also include the student satisfaction survey results gathered from registered students in the semester as the feedback for our method.

This article was organized into six sections; 1) introduction 2) related works, including the online learning situation and research before and during COVID-19 3) methodology for our policy enforcement method and an online learning guideline 4) results of student satisfaction 5) discussion of the developed enforcement and guideline and 6) conclusion.

\section{Related Works}

To understand the current situation in current online learning, in this section, we defined online learning and explored the usage of online learning before and during the COVID-19 pandemic. This section starts with defining terms related to online learning, and the next topic explores the most popular online learning approach in Higher Education around the world, i.e., MOOC. After that, a literature survey about pedagogy for online learning is described, including Mobile Learning. Finally, the section ends with the online learning efforts during COVID-19 around the world. 


\subsection{Online learning in higher education before COVID-19}

Online learning in higher education is not a new approach, but it has been used for specific circumstances. Since the cost of college tuition is rising faster than inflation, online learning is a way to spread the cost of higher education. Pure online learning can be classified as Distance Learning since it delivers over the internet nowadays, and partly online and in-class learning is called Hybrid Learning or Blended Learning. Many studies [2], [3] concluded that there are no significant differences in student outcomes between online learning and face-to-face learning. However, Bernard et. al. [4] stated that synchronous activities were better for traditional face-to-face learning, but asynchronous activities favored distance learning. The differences in time spent in the class also result in different outcomes. So, online learning has great potential to provide a world-class education to anyone, anywhere, and anytime for some asynchronous content as long as the learners have access to the internet.

Before the COVID-19 crisis, Wotto ]2[ defined the concept and analyzed the current trends in higher education distance learning (HEDL) in Canada, the United States, and France. Since internet usage among early adults in most OECD countries is almost $100 \%$, HEDL via the internet is more than plausible. The most common usage of HEDL is via MOOCs with the United States hosting most MOOC platforms, i.e., Coursera, EdX, etc. Most of those courses are produced by top universities, while $80 \%$ of US universities also publish their courses online. In contrast, $70 \%$ of their registered learners are located outside the U.S. territory. Therefore, learners from all over the world increasingly invest time and money for education via the internet.

Higher education internationalization has grown its enrollment rate significantly, and online learning provided access and flexibility. For example, HEDL internationalization in the US delivered through mega portals, which offered over 170,000 courses from 3,050 educational institutions in 110 countries, which accounted for 13,000 programs, including over 9,000-degree programs and 3,000 short programs. In contrast, HEDL in national education was still an addition to traditional in-class education.

In Canada, HEDL had an $11 \%$ increase per year in its online enrollment rate in 2015, and it accounted for $16 \%$ of the total university registrations. In Europe, French aims to develop a potential MOOCs market of 400 million students by 2030. In China in 2019, there are over 12,500 MOOC courses; more than 200 million person-times of college students and social learners participate in the study online, and up to 65 million person-time of college students obtained MOOC credits ]3[. Therefore, the entire world embraced online learning full-heartedly, especially for higher education.

\subsection{Pedagogy for online learning}

Even though online learning, including MOOC, gains its popularity over time, there are still gaps to improve the effectiveness of its pedagogy. Many studies had been explored in this space. The results from secondary data showed that Blended Learning could be applied successfully while Online Learning was struggling according to the pass rate [4]. Blended Learning can support various activities, i.e., using 
online discussion activities as formative assessment [5]. The results from comparing online and face-to-face showed that weekly activity is the most valuable strategy in both online and face-to-face while course structure/sequence and online class discussion are much more valuable than those in the face-to-face class [6]. These strategies should be implemented in Online Learning effectively.

Di Jing and Dong-chen Zhao [7] developed a MOOC Satisfaction Scale (MSS) to measure university's students' satisfaction with MOOC. After a thorough statistical analysis, the final version of the MSS included 5 dimensions with 28 items. The MSS was used in our teaching guideline to create a MOOC with high satisfaction.

ICT must be used in online courses inevitably. Alogiannakis \& Papadakis [8] found that younger teachers were willing to accept ICT in pedagogy than the older ones, though they were from small-town schools. Rodrigo Urcid Puga [9] applied FIT Model (Flexible, Interaction, and Technology) to an online course in for a group of instructors on different campuses. The course used CANVAS and Zoom to deliver content and communication. The satisfaction survey showed very high satisfaction with face-to-face classroom preference.

\subsection{Mobile learning}

Mobile Learning is an indispensable tool for online learning. Learners can access educational material anytime anywhere via their smartphones. Smartphone learners can finish course material $45 \%$ faster than learners with computers, and $43 \%$ of mobile users can enhance their learning productivity over non-mobile users [10]. With good learning design, a mobile app can enhance the learners' self-belief in learning achievement [11].

The four basic elements of mobile learning pedagogy include technology, pedagogy, content, and social interaction [12]. According to the instructor's aspect, the factors influencing mobile learning include teacher status, type of institution, educational technology research, implementing pedagogical innovations regularly, and belief that mobile devices are appropriate [13]. The factors that affect college students' adoption of mobile learning include task characteristics, task technology fit, mobile learning performance expectation, social impact, resource optimization, and perceived cost [14]. A clear learning module can help students' self-learning. When mobile learning is used in the third space, i.e., between formal classroom and selfeducation, it should support these properties: switching across scenes, emphasizing student to practice in real-life problems, including interactive communication, and supporting the teachers as experienced peers instead of authority roles [15]. However, mobile learning success in one context may not always be accepted in another due to culture [16]. While mobile learning is only a tool for online learning, many approaches in the studies above can be applied to online learning as well.

\subsection{Online learning during COVID-19}

While COVID-19 is spreading all over the world, and many governments announced to lock down their countries, including schools and universities. The World 
Bank [17] collects emerging education technologies to support educational technology utilization in remote learning during the COVID-19 pandemic, i.e., TV, radio, online video broadcasting, CDs distribution, LMS, such as Moodle, Google Classroom, or Microsoft Teams. UNESCO [18] also compiles a list of educational applications, platforms, and resources to facilitate student learning during COVID-19 school closure.

Some example of empirical research on using education technologies, i.e., LMS, during COVID-19 is given as the followings. Papadakis et al. [19] investigated how Greek university students use Moodle as an LMS on mobile phones. They concluded that, though Moodle supports many activities, most of them used it only for a content repository and engage only low-stake activities. The top 3 reasons for not-using the LCMS are

1) Heavy workload with no time to create an e-course

2) Need help to create e-content

3) Need training to use the platform [20].

Therefore, in our university, we set up an online training and a support team for our faculties.

Basilaia et al [21] identified the requirements of online-learning platforms during COVID-19 to have the following properties:

1) Video conferencing with at least 50 students in the session

2) Discussions with students can be done to keep classes organic

3) Lecture must be recorded for students with no high-speed internet

4) Lectures are accessible in mobile phones and computers

5) Possibility of watching and rewinding already recorded lectures

6) Assignments are handled via online methods

In this article, they used Google's G-Suite for education. Likewise, our university decided to use Google's G-Suite for education as well.

On the instructor's side, Teaching professionals in computer science in the UK showed a more positive attitude towards online learning, teaching, and assessment [22]. On the student's side, online learning could not make students feel connected, maintain their routine, nor provide them some hours of structured learning [23]. The students indicate a poor relationship with teachers and peers while they are feeling anxiety and stress [24]. Only replacing classroom learning with online learning without changing the pedagogy methods can even reduce the quality of student learning [25]. Therefore, an effective online learning approach is inevitably crucial during the lockdown.

The challenges of online learning are:

1) Unequal Distribution of ICT Infrastructure

2) Quality of Education

3) Digital Illiteracy

4) Digital Divide

5) Technology cost \& Obsolescence [26]. 
These challenges must be considered and mitigated for effective online learning.

During COVID-19, various empirical research about online learning pedagogy had been conducted. Though online platforms can extend the space and time of teaching, online learning lacks emotional guidance [27]. Effective online learning should not only contain video clips, but also include the course's in-class activities, and online participation should be responsive actively in timely manners [28]. However, the workload of both students and teaching staffs increased as well [29]. Providing an abundance of learning resources and allowing students the freedom of selecting the ones that best facilitate their learning was a viable decision for the online course during COVID-19 [30]. One way is to teach through a Hybrid Classroom allowing online and physical participants to interact during a live session during the lockdown [31]. In addition, videoconferencing platforms (Zoom, Microsoft Teams, and Cisco Webex) are an important component for online learning, and their performance was not significantly different [32]. With all facilities and convenience, the degree of plagiarism during distance learning increased comparing to the plagiarism of face-to-face learning [33].

Various research had been done during the COVID-19 shutdown, but no literature mentioned how to implement online learning at the university-wide scale. Based on the related works above, for our university-wide online learning during the COVID19 shutdown, we proceeded with our approach with a policy enforcement method and a teaching guideline for our faculties. We choose Google Classroom as our universitywide LMS and Google Meet as our video conference since we already have Google G-Suite for education for our complementary e-learning. The suite has been reliable with very little downtime, and it is famous for its user-friendliness for new users. We also provide a training course and a support team to create online content for faculties. Lastly, we conduct an active process to control their teaching quality, as described in the next section.

\section{$3 \quad$ Methodology}

At the beginning of April, our university executives announced a university-wide online learning policy during the Summer Semester, and they specified the policy of online learning classes. The policy specified that all lecture-based courses must organize with online learning, which must have both video clips and live sessions in every week for the class effectiveness. As the centre of Learning and Teaching Innovation, we implemented the university-wide online learning policy enforcement via four steps, including: 1) an online training, 2) an online teaching guideline, 3) a teaching quality control, and 4) a teaching assessment survey. The details in each step are as the followings. The details in each step are as the followings. 


\subsection{Online training}

First, we created an online training course via Google Classroom. We choose Google Classroom as our university-wide Learning Management System since we already have Google G-Suite for education for our complementary e-learning. Also, the suite has shown its reliability with very little downtime, and any new users can start to use Google products with a little learning curve.

Then, we created the training contents of 10 video clips, including:

1. How to record a video clip with PowerPoint

2. How to record a video clip with LOOM/OBS Studio

3. How to record a video clip with a webcam with Google Meet

4. How to edit video clips with Window 10's Video Editor

5. How to create a classroom and add students in Google Classroom

6. How to publish your instructional media, manage and grade assignments, and export scores with Google Classroom

7. How to have a live session with Google Meet

8. How to have a student's presentation session with Google Meet

9. How to proctor with Google Meet

10. How to create an online quiz with Google Form

Obtaining the concept of Microlearning, we divide the video clips into bite-size (shorter than 5 minutes) for each topic, so the faculties can watch the clips in their spare time, and they can search for the clips based on their interests easily.

Then, we invited all faculties who would teach during the Summer Semester to join our course. The University Academic Affairs Office announced the work from home policy and online learning class for the Summer Semester in early April 2020. The university also closed during the third week of April as its annual vacation, while the Summer Semester started on May 18th. Therefore, we had only a few weeks to prepare all faculties to teach online for the semester without a chance to meet up with them in person. Therefore, the only way to communicate with them is via electronic methods, including emails, LINE, and phone calls.

The communication while all faculties are working from home is very difficult. We decided to implement many ways of communication. First, we passed our course's class code via the deans of all faculties in the university. Then, we invited them via the university's emails individually. Finally, we posted our Google Classroom invitation and class code in the university LINE group, and we asked the head of their departments to confirm the subscription with them. As a result, we have $88.43 \%$ of the 121 faculties we invited.

\subsection{Online teaching guideline}

In the second week, we released a guideline for online teaching. The guideline includes 10 items as the best practices the instructors should follow to create a good online course. The details of the guideline are as the followings: 
1. The course includes video clips for all 15 sessions in the semester.

2. Each video clip is shorter than 10 minutes.

3. The course includes weekly live sessions for interactive activities, such as Q\&A, discussion, etc.

4. The live session is shorter than 30 minutes and followed by a break.

5. Any live sessions are recorded for future access.

6. (optional)A Digital Textbook is included for self-paced learning.

7. All documents and instructional media are posted in Google Classroom for student access.

8. All documents and media are organized for easy access and easy reference in Google Classroom, i.e., ordered by week and specified the topics.

9. The course includes exercises or activities for formative assessment in each topic.

10. The course includes an online summative assessment, i.e., online exams, online presentations, etc.

The guideline was in a Google Form to have the instructors assess their courses by themselves. We also communicate the guideline via our training Google Classroom, the university LINE group, and e-mails.

\subsection{Teaching quality control}

After releasing our online teaching guideline, to assure the teaching quality, we scheduled assignments for all instructors, including:

- Course Syllabus: This includes the course description, schedule time, instructor's contacts, class policy, textbook, references, and grading allocation.

- Online Lesson Plan: This includes each session's topics, objectives, content delivery methods (video clips or live sessions), activities, and formative assessment methods.

- Google Classroom ID of their online classes

- Video Clips: The instructors assigned to submit in their Google Classroom for 5 sessions per week.

Three weeks before the semester started, the instructors had to submit their course syllabus, online lesson plan, and the Google Classroom ID. Then, in the week after, they were assigned to submit their video clips for their first 5 sessions. After that, they were assigned to submit their video clips for session 6th-10th. Finally, they must submit their video clips for the last 5 sessions. All submission statistics were informed to their deans and the Vice President in the Academic Affairs of the university.

There were four teaching advisors in our Learning and Teaching Innovation Centre to check their submissions according to the guideline and give feedback for improvements weekly. We also conducted a teaching assessment survey from students taking their courses to reflect their online teaching experience. 


\subsection{Teaching assessment survey}

The instrument used is the satisfaction of students from a survey for the online classes under the enforcement of the university online learning policy. There were two parts of our survey, including the close-ended part and the open-ended part. The close-ended survey included 10 questions using a 5-Likert scale. The closed-ended questions were corresponding to the previously stated research as shown in Table 1.

Table 1. The Online Teaching Survey Questions and Their References

\begin{tabular}{|l|l|l|}
\hline \multicolumn{1}{|c|}{ Questions } & \multicolumn{1}{|c|}{ References } \\
\hline 1. & $\begin{array}{l}\text { The students have an opportunity to practice analytical thinking, creativity, } \\
\text { problem-solving, and collaboration via this online course. }\end{array}$ & $\begin{array}{l}\text { [6], MSS CI: Q11 [7], } \\
\text { Basilaia (2) [21], [28] }\end{array}$ \\
\hline 2. & $\begin{array}{l}\text { The students learn from multi-media, i.e., videos, infographics, animations, } \\
\text { digital-learnings, games, social media, etc. }\end{array}$ & MSS PR: Q39 [7], [30] \\
\hline 3. & $\begin{array}{l}\text { The instructional multi-media (videos, animations, games, etc.) have appro- } \\
\text { priate lengths. }\end{array}$ & MSS CI: Q5 [7] \\
\hline 4. & The students can access all media conveniently. & Basilaia (3-5) [21] \\
\hline 5. & The live sessions are not too long. & MSS CI: Q5 [7] \\
\hline 6. & The students can access the LMS conveniently. & MSS PR: Q38 [7] \\
\hline 7. & $\begin{array}{l}\text { The students can receive suggestions and advice from the instructors conven- } \\
\text { iently. }\end{array}$ & MSS TSI: Q23 [7] \\
\hline 8. & $\begin{array}{l}\text { The online assessments (i.e., exams, projects, presentations, etc.) are appro- } \\
\text { priate to the course. }\end{array}$ & $\begin{array}{l}\text { MSS AE: Q29 [7], } \\
\text { Basilaia (6) [21] }\end{array}$ \\
\hline 9. & The students have a good attitude toward online learning. & MSS SL: Q19 [7] \\
\hline 10. & $\begin{array}{l}\text { The students have learned all topics stated in the course objectives and lesson } \\
\text { plan. }\end{array}$ & MSS CI: Q1 [7] \\
\hline
\end{tabular}

The survey questions covered all five dimensions in MSS [7] and online learning requirements in [21]. We would like the instructors to have more freedom in their classes, so we implemented only a set of questions from MSS. Besides, the survey questions covered all 10 items in our online teaching guideline with a broader sense.

Two subject-matter experts validated the survey questionnaire. Both were university academic executives. One had expertise in modern pedagogy, and another one had expertise in educational quality assurance.

The summer semester of 2019 lasted from May 18th until the end of June 2020. We conducted a survey to assess our university online classes for the semester from June 22nd until July 3rd, 2020 as the feedback from students taking the online classes. The population taken was all students registered in the summer semester of 2019.

The survey was conducted based on a convenience sampling design, and everyone was free to decide their participation. We sent out a web link of the survey via the university mobile application for students, and we posted it in our training Google Classroom. After we released the survey for a week, there was only a small number of students responded to the survey. Therefore, we decided to post the survey in all instructor's Google Classroom to collect more data. 


\section{$4 \quad$ Results}

Among 121 instructors registering the training Google Classroom, these are the results of our training course:

- Only 57 instructors were attending our training programs as they informed us that their courses are lecture-based. The university policymakers did not include the non-lecture-based courses into the university's online learning policy at this time. So, other 64 instructors claimed that their courses are not lecture-based, and they managed their classes in some other ways rather than online lecture-based courses.

- 49 from 57 instructors (85.96\%) submitted their course syllabus and online lesson plans completely.

- Only 35 instructors $(61.40 \%)$ submitted their video clips for their first 5 sessions.

- Only 12 instructors (21.05\%) submitted their video clips for their week 6-10 by our submission schedule.

Due to the communication problem, we had to extend our training program for another week. the training schedule was overlapped with the semester. So, they must teach and produce their media at the same time. Therefore, they could not complete our assignments on time. However, we accomplished our goal: they learn good practice to conduct their online course by producing the course syllabus, online lesson plan, and video clips.

After receiving the assessment survey results from 669 students from all faculties in the university, the results are shown in Table 2. The scoring system is a 5-point Likert Scale, including strongly disagree (1), disagree (2), neutral (3), agree (4), and strongly agree (5).

Table 2. The Online Teaching Survey Results

\begin{tabular}{|l|l|c|}
\hline \multicolumn{1}{|c|}{ Questions } & Average Score \\
\hline 1. & $\begin{array}{l}\text { The students have an opportunity to practice analytical thinking, creativity, problem- } \\
\text { solving, and collaboration via this online course. }\end{array}$ & 4.62 \\
\hline 2. & $\begin{array}{l}\text { The students learn from multi-media, i.e., videos, infographics, animations, digital- } \\
\text { learnings, games, social media, etc. }\end{array}$ & 4.58 \\
\hline 3. & $\begin{array}{l}\text { The instructional multi-media (videos, animations, games, etc.) have appropriate } \\
\text { lengths. }\end{array}$ & 4.52 \\
\hline 4. & The students can access all media conveniently. & 4.58 \\
\hline 5. & The live sessions are not too long. & 4.47 \\
\hline 6. & The students can access the LMS (Google Classroom) conveniently. & 4.57 \\
\hline 7. & The students can receive suggestions and advice from the instructors conveniently. & 4.61 \\
\hline 8. & $\begin{array}{l}\text { The online assessments (i.e., exams, projects, presentations, etc.) are appropriate to } \\
\text { the course. }\end{array}$ & 4.56 \\
\hline 9. & The students have a good attitude toward online learning. & 4.44 \\
\hline 10. & The students have learned all topics stated in the course objectives and lesson plan. & 4.61 \\
\hline & \multicolumn{1}{|c|}{ Overall } & 4.56 \\
\hline
\end{tabular}


We can see from Table 2 that the scoring is between 4.44 and 4.62 . The highest score is the question\#1, while the lowest score is question\#9. However, the scores among all questions are not much different. The important point here is the student's attitude against online learning (question\#9) is very high.

Table 3 shows the number of respondents in each faculty. The Faculty of Media and Game has only two respondents because they opened only one course for only those two students to meet with their graduation requirements. Note that, the number of respondents may not actually be proportional to the number of students in the entire university, but they are actually registered students in the Summer Semester, which is from our population.

Table 3. The Number of Respondents for Each Faculty

\begin{tabular}{|l|c|}
\hline \multicolumn{1}{|c|}{ Faculty } & Number of Respondents \\
\hline Media \& Game & 2 \\
\hline Business & 69 \\
\hline Medicine & 39 \\
\hline Engineering & 55 \\
\hline Fine Arts & 75 \\
\hline Public Administration & 33 \\
\hline Education & 93 \\
\hline Law & 134 \\
\hline Communication Arts & 24 \\
\hline Arts & 145 \\
\hline Total & 669 \\
\hline
\end{tabular}

If we look at the assessment score by faculty, as shown in Fig. 1, we can see that all faculties received a very high assessment score, ranging from 4.20 to 5.0. The Faculty of Communication Art earns the lowest score because they violated our guideline as depicted in Table 4.

Table 4. shows each question score by Faculty. The question number is corresponding to the question listed in Table 1 . We can see that all faculties received high assessment scores in all questions, ranging from 3.88 to 5.0. As stated before, the Faculty of Communication Art earns the lowest average assessment score because they violated our guideline by conducting lengthy lecture-based live sessions. These lengthy sessions caused too little time for skill-based activities, as assessed by Question\#1, and consequently caused dissatisfaction for online learning in overalls in Question\#9. 


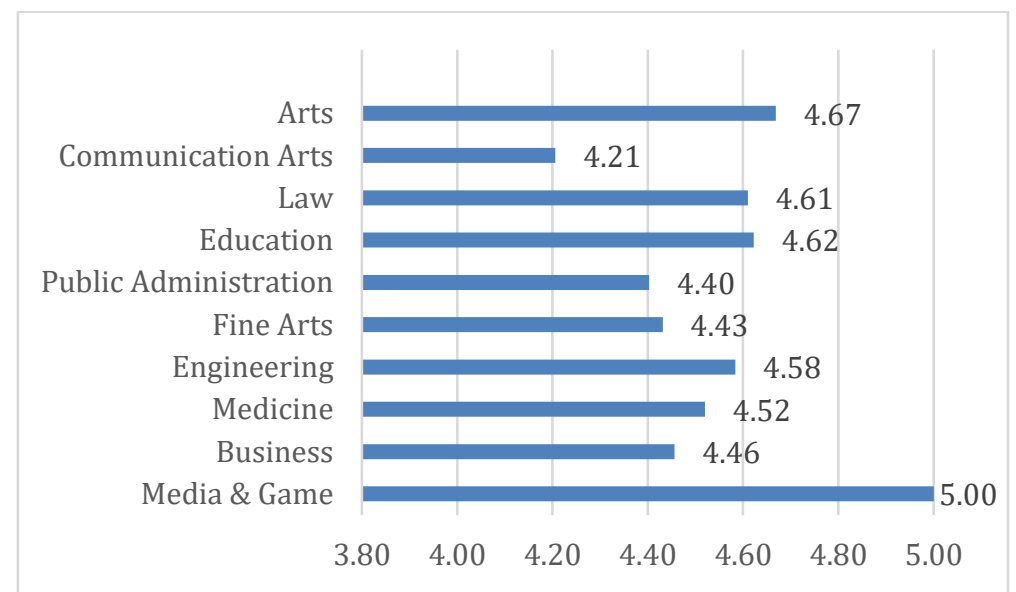

Fig. 1. Online Assessment Score by Faculty

Table 4. Online Teaching Assessment Question Score by Faculty

\begin{tabular}{|c|c|c|c|c|c|c|c|c|c|c|}
\hline Question\# & $\begin{array}{c}\text { Fine } \\
\text { Arts }\end{array}$ & Arts & $\begin{array}{c}\text { Communi- } \\
\text { cation Arts }\end{array}$ & Law & Education & $\begin{array}{c}\text { Public } \\
\text { Administra- } \\
\text { tor }\end{array}$ & $\begin{array}{c}\text { Engi- } \\
\text { neering }\end{array}$ & $\begin{array}{c}\text { Medi- } \\
\text { cine }\end{array}$ & $\begin{array}{c}\text { Media } \\
\text { Business } \\
\text { \& } \\
\text { Game }\end{array}$ \\
\hline 1 & 4.57 & 4.71 & 4.16 & 4.7 & 4.7 & 4.58 & 4.64 & 4.49 & 4.51 & 5.00 \\
\hline 2 & 4.48 & 4.68 & 4.37 & 4.67 & 4.53 & 4.37 & 4.53 & 4.69 & 4.51 & 5.00 \\
\hline 3 & 4.37 & 4.62 & 4.34 & 4.55 & 4.55 & 4.36 & 4.55 & 4.56 & 4.47 & 5.00 \\
\hline 4 & 4.38 & 4.70 & 4.42 & 4.63 & 4.66 & 4.42 & 4.64 & 4.44 & 4.52 & 5.00 \\
\hline 5 & 4.40 & 4.61 & 4.00 & 4.52 & 4.58 & 4.27 & 4.46 & 4.33 & 4.36 & 5.00 \\
\hline 6 & 4.48 & 4.66 & 4.21 & 4.56 & 4.67 & 4.49 & 4.59 & 4.54 & 4.49 & 5.00 \\
\hline 7 & 4.48 & 4.73 & 4.21 & 4.67 & 4.66 & 4.36 & 4.63 & 4.59 & 4.58 & 5.00 \\
\hline 8 & 4.36 & 4.64 & 4.37 & 4.64 & 4.64 & 4.49 & 4.67 & 4.46 & 4.41 & 5.00 \\
\hline 9 & 4.27 & 4.59 & 3.88 & 4.43 & 4.57 & 4.27 & 4.51 & 4.46 & 4.39 & 5.00 \\
\hline 10 & 4.51 & 4.73 & 4.13 & 4.67 & 4.71 & 4.43 & 4.65 & 4.64 & 4.37 & 5.00 \\
\hline average & 4.43 & 4.67 & 4.21 & 4.60 & 4.63 & 4.40 & 4.59 & 4.52 & 4.46 & 5.00 \\
\hline
\end{tabular}

\section{$5 \quad$ Findings and Discussion}

The research question needed to be answered is about the appropriate enforcement approach and teaching guideline to all instructors in a university to deliver their course $100 \%$ online with student satisfaction. The results showed high student satisfaction with the online courses. The cause of the positive effects of our approach on student satisfaction is in two folds. Firstly, our teaching guideline includes all four components of mobile learning [12], all five dimensions in MSS [7], and all six items in [21]. Secondly, we enforced the university policy with a strong and strict quality control process.

The four basic elements of mobile learning pedagogy include technology, pedagogy, content, and social interaction [12]. Our guideline suggested basic requirements for an online course while our survey questions measured the same properties in a 
broader sense. According to the technology element, our guideline included four technologies, including, video clips, live sessions, digital textbooks, and Google Classroom as LMS. For pedagogy, our guideline suggested microlearning with weekly activities while our survey questions also measure 21 st-century-skills practice. For the content, our guideline suggested both short video clips and a digital textbook as a starter while our survey questions suggested a wider range of contents. Finally, social interaction in our guideline was conducted through live sessions, and the survey questions measured the communication between instructors and students.

The five dimensions in MSS [7] included content and instruction (CI); teacherstudent interaction (TSI); assessment and examination (AE); platforms and resources (PR), and student learning (SL). Our guideline included the content through Google Classroom as the LMS, and the instruction through the video clips, live sessions, and weekly activities. Teacher-student interaction in our guideline also proceeded through the LMS and the live sessions. Assessment and examination in the guideline proceed through weekly activities, online examinations, or online presentations. We also measured this dimension in our survey question. The platform used in our guideline is Google Classroom, and the resources included video clips and digital textbooks as the basic requirement. Finally, student learning is measured in the survey questions as the attitude toward online learning.

The six requirements of online-learning platforms [21] are:

1) Video conferencing with at least 50 students in the session

2) Discussions with students can be done to keep classes organic

3) Lecture must be recorded for students with no high-speed internet

4) Lectures are accessible in mobile phones and computers

5) Possibility of watching and rewinding already recorded lectures

6) Assignments are handled via online methods

Our guideline provided video conferencing through Google Meet, which can support up to 250 participants. The discussions were done through live sessions and weekly activities. Lectures delivering as video clips and live sessions must be recorded for future access in our guideline. All lectures were posted in Google Classroom, which is accessible on mobile phones and computers. Recorded lectures were video files, which can be watching and rewinding. Finally, assignments and examinations were conducted in online methods as mentioned in our guideline.

\section{Limitations}

The contribution of this article is the policy enforcement method and teaching guideline for online learning for the university-wide scale. However, this study only covers the results of student satisfaction. The more important achievement should be concentrated on the student's academic performance. More research must be conducted to improve online learning on a university-wide scale which aims at student's academic performance. 


\section{Conclusion}

During Thailand's COVID-19 lockdown, all university must continue their classes in the Summer Semester in an online format. According to our university's policy, we set up a policy enforcement approach to support online learning and create a guideline for our instructors. We also conducted a quality control process, and an assessment to obtain feedback from our students. The results showed that, even though many instructors could not finish all teaching materials before the semester started as planned, most students were satisfied with their online class with an average score of 4.54 on a 5-point Likert Scale.

In our future works, we will continue our method in the next semester when online learning is still needed as the new normal. Many challenges still exist, i.e., more numbers of faculties and courses. We also collaborate with the university's IT department to make sure that the university's IT infrastructure supports a massive amount of internet bandwidth as many classes go live simultaneously.

\section{References}

[1] World Health Organization, "Q\&A on coronaviruses (COVID-19)," World Health Organization, [Online]. Available: https://www.who.int/emergencies/diseases/novel-coronavirus2019/question-and-answers-hub/q-a-detail/q-a-coronaviruses . [Accessed 23 August 2020].

[2] M. Wotto, "The Future High Education Distance Learning in Canada, the United States, and France: Insights from Before COVID-19 Secondary Data Analysis," Journal of Educational Technology Systems, vol. 0, no. 0, pp. 1-20, 2020. https://doi.org/10.1177/004723 $\underline{9520940624}$

[3] M. Wu, "A Path for Private Colleges and Universities to Improve Teaching Quality Against the Background of Open Online Course Construction," in 2nd International Conference on Contemporary Education, Social Sciences and Ecological Studies (CESSES 2019), Moscow, Russia, 2019. https://doi.org/10.2991/cesses-19.2019.16

[4] P. T. V. Anh and H. T. T. Nguyen, "Teaching Fundamental Courses in Vietnam: Transitioning from Blended Learning Approach to Online Learning Approach," in ICDEL 2020, Beijing, China., 2020. https://doi.org/10.1145/3402569.3402592

[5] G. Xiaochun and W. Yiwei, "Experiments on Blended Learning and its Formative Assessment for Engineering Majors in Universities," in ICDEL 2020, Beijing, China, 2020. https://doi.org/10.1145/3402569.3402576

[6] D. Basu and N. Gopalkrishna, "Evaluation of Course Strategies: Face-to-Face vs. Online," in ICER '20, Virtual Event, New Zealand, 2020. https://doi.org/10.1145/3372782.3408121

[7] D. Jing and D.-c. Zhao, "Developing a Scale to Measure University Student's Satisfaction with MOOC," in ICDEL 2020, Beijing, China., 2020.

[8] M. Kalogiannakis and S. Papadakis, "The dual form of further education of educators in ICT: technological and pedagogical training," in Proceedings of the 8th International Conference on Computer Based Learning in Science, Heraklion, 2007. 
[9] R. U. Puga, "Perception of the FIT Mode (TEC21 Model) of the Course: Photography and Digital Image," in ICDEL 2020, Beijing, China, 2020. https://doi.org/10.1145/3402569.34 $\underline{02571}$

[10] Docebo, "e-Learning trends," 2018. [Online]. Available: https://fliphtml5.com/duyqh/wff r/basic .

[11] C. Peechapol, J. Na-Songkhla, S. Sujiva and A. Luangsodsai, "Development of Smartphone Application Based on the Theory of Planned Behaviour to Enhance SelfEfficacy for Online Learning," International Journal of Interactive Mobile Technologies (iJIM), vol. 12, no. 4, pp. 135-151, 2018. https://doi.org/10.3991/ijim.v12i4.8715

[12] I. Lestari, A. Maksum and C. Kustandi, "Mobile Learning Design Models for State University of Jakarta, Indonesia," International Journal of Interactive Mobile Technologies, vol. 13, no. 9, pp. 152-171, 2019. https://doi.org/10.3991/ijim.v13i09.10987

[13] J. Romero-Rodríguez, I. Aznar-Díaz, F. Hinojo-Lucena and G. Gómez-García, "Mobile Learning in Higher Education: Structural Equation Model for Good Teaching Practices," IEEE Access, vol. 8, pp. 91761-91769, 2020. https://doi.org/10.1109/access.2020.2994967

[14] P.-C. Li, W.-J. Kong and W.-L. Zhou, "Research on the Mobile Learning Adoption of College Students Based on TTF and UTAUT," in ICDEL 2020, Beijing, China, 2020.

[15] Y. Zhou and X. Hu, "The Third Space and Ideological \& Political Education in Colleges Based on M-Learning," in ICDEL 2020, Beijing, China, 2020.

[16] J. Eppard, Z. Hojeij, P. Ozdemir-Ayber, M. Rodjan-Helder and S. Baroudi, "Using Mobile Learning Tools in Higher Education: A UAE Case," International Journal of Interactive Mobile Technologies, vol. 13, no. 11, pp. 51-69, 2019. https://doi.org/10.3991/ijim.v13 i11.10823

[17] World Bank's Edtech team, "How countries are using edtech (including online learning, radio, television, texting) to support access to remote learning during the COVID-19 pandemic," 2020. [Online]. Available: https://www.worldbank.org/en/topic/edutech/brief/ how-countries-are-using-edtech-to-support-remote-learning-during-the-covid-19-pandemic . [Accessed 23 August 2020]. https://doi.org/10.1596/33499

[18] UNESCO, "Distance learning solutions," [Online]. Available: https://en.unesco.org/ covid19/educationresponse/solutions . [Accessed 23 August 2020].

[19] S. Papadakis, M. Kalogiannakis, E. Sifaki and N. Vidakis, "Evaluating Moodle use via Smart Mobile Phones. A case study in a Greek University," EAI Endorsed Transactions on Creative Technologies, vol. 5, no. 16, pp. 1-9, 2018. https://doi.org/10.4108/eai.10-4$\underline{2018.156382}$

[20] A. Kirkova-Bogdanova and D. Taneva, "ICT Usage and E-Courses Development by Faculty Staff in Healthcare Majors at Medical University - Plovdiv," TEM Journal, vol. 9, no. 2, p. 731-739, May 2020. https://doi.org/10.18421/tem92-41

[21] G. Basilaia, M. Dgebuadze, M. Kantaria and G. Chokhonelidze, "Replacing the classic learning form at universities as an immediate response to the COVID-19 virus infection in Georgia," International Journal for Research in Applied Science \& Engineering Technology, vol. 8, no. III, 2020. https://doi.org/10.22214/ijraset.2020.3021

[22] T. Crick, C. Knight, R. Watermeyer and J. Goodall, "The Impact of COVID-19 and "Emergency Remote Teaching" on the UK Computer Science Education Community," in United Kingdom \& Ireland Computing Education Research conference. (UKICER '20), Glasgow, United Kingdom, 2020. https://doi.org/10.1145/3416465.3416472 
[23] A. Khattar, P. R. Jain and S. M. K. Quadri, "Effects of the Disastrous Pandemic COVID 19 on Learning Styles, Activities and Mental Health of Young Indian Students - A Machine Learning Approach," in Proceedings of the International Conference on Intelligent Computing and Control Systems (ICICCS 2020), Madurai, India, 2020. https://doi.org/10.1109/ iciccs48265.2020.9120955

[24] R. D. Michele, "Benefits, drawbacks and psychological impact of online lectures," in GoodTechs '20, Antwerp, Belgium, 2020.

[25] I. Vlasov, "Legal and pedagogical aspects of e-education," in International Conference Engineering Technologies and Computer Science (EnT), Moscow, Russia, 2020. https://doi. org/10.1109/ent48576.2020.00034

[26] S. Dhawan, "Online Learning:A Panacea in the Time of COVID-19 Crisis," Journal of Educational Technology Systems, vol. 49, no. 1, pp. 5-22, 2020.

[27] Y. He, "Research on Online Teaching of Music Performance Based on Diversification and Intelligence," in International Conference on E-Commerce and Internet Technology (ECIT), Zhangjiajie, China, 2020. https://doi.org/10.1109/ecit50008.2020.00050

[28] H. Yuan, A. Xu, J. Huang and L. Wang, "Constructing MOOC Ecosystem: Putting MOOC Resources into Use," in ICDEL 2020, Beijing, China, 2020. https://doi.org/10.1145/34025 $\underline{69.3402575}$

[29] A. S. Alam, E. Lau, C. Oh and K. K. Chai, "An Alternative Laboratory Assessment Approach for Multimedia Modules in a Transnational Education (TNE) Programme during COVID-19," in Transnational Engineering Education using Technology (TREET), Glasgow, 2020.

[30] M. L. George, "Effective Teaching and Examination Strategies for Undergraduate Learning During COVID-19 School Restrictions," Journal of Educational Technology Systems, vol. 49, no. 1, pp. 23-48, 2020.

[31] T. Triyason, A. Tassanaviboon and P. Kanthamanon, "Hybrid Classroom: Designing for the New Normal after COVID-19 Pandemic," in IAIT2020, Bangkok, Thailand, 2020. https://doi.org/10.1109/treet50959.2020.9189756

[32] D. Pal, V. Vanijja and S. Patra, "Online Learning During COVID-19: Students' Perception of Multimedia Quality," in Proceedings of International Conference on Advances in Information Technology (IAIT2020), Bangkok, Thailand, 2020. https://doi.org/10.1145/340 $\underline{6601.3406632}$

[33] P. L. Ogrutan and L. E. Aciu, "Aspects of Academic Performance and Ethics in the Transition to eLearning Caused by the Actual Pandemic - A case study," TEM Journal, vol. 9, no. 2, p. 656-661, May 2020. https://doi.org/10.18421/tem92-31

[34] National Research Center for Distance Education and Technological Advancements, "DETA Research Center Community | No Significant Difference," 2019. [Online]. Available: https://detaresearch.org/research-support/no-significant-difference/ . [Accessed 238 2020].

[35] T. Nguyen, "The Effectiveness of Online Learning: Beyond No Significant Difference and Future Horizons," MERLOT Journal of Online Learning and Teaching, vol. 11, no. 2, June 2015.

[36] R. M. Bernard, P. C. Abrami, Y. Lou, E. Borokhovski, A. Wade, L. Wozney, P. A. Wallet, M. Fiset and B. Huang, "How Does Distance Education Compare with Classroom Instruc- 
tion? A Meta-Analysis of the Empirical Literature.," Review of Educational Research, vol. 74, no. 3, p. 379-439, 2004. https://doi.org/10.3102/00346543074003379

\section{Author}

Nuengwong Tuaycharoen is an assistant professor in Computer Engineering and a director of the Center of Learning and Teaching Innovation at Dhurakij Pundit University (DPU), Thailand. She received her B. Eng degree with honours in Computer Engineering from Chulalongkorn University, Thailand. She received her M.S. and Ph.D. in Electrical and Computer Engineering from the University of Maryland, College Park, USA. Her interests are in Software Development, Web and Mobile Application Development, and Online and Active Learning.

Article submitted 2020-08-31. Resubmitted 2020-10-21. Final acceptance 2020-10-21. Final version published as submitted by the authors. 